УДК 339.56:338.43:005.52

DOI: 10.15673/fie.v13i3.2128

\author{
Антонюк П.О. \\ кандидат економічних наук, науковий співробітник \\ відділ ринкових механізмів і структур \\ Інститут проблем ринку та економіко-екологічних \\ досліджень НАН України \\ Французький бульвар, 29, м. Одеса, Україна, 65044 \\ E-mail: paul_antonyuk@ukr.net \\ ORCID ID: 0000-0002-8100-2563 \\ Ступницька Т.М. \\ кандидат економічних наук, доцент \\ кафедра обліку та аудиту \\ E-mail: t.stupnitska@gmail.com \\ ORCID ID: 0000-0002-2517-2795
}

\author{
Антонюк О.П. \\ кандидат економічних наук, доцент \\ кафредра обліку та аудиту \\ E-mail: olegantoni@ukr.net \\ ORCID ID: 0000-0002-9182-4982
}

\section{Баранюк X.O. \\ асистент}

кафедра обліку та аудиту

Одеська національна академія харчових технологій вул. Канатна, 112, м. Одеса, Україна, 65039

E-mail: baranyuk.kristina@gmail.com ORCID ID: 0000-0002-3346-0332

\title{
АНАЛІЗ СУЧАСНОГО СТАНУ ЗОВНІШНЬОЇ ТОРГІВЛІ УКРАЇНИ АГРОПРОДОВОЛЬЧИМИ ТОВАРАМИ
}

Основою дослідження є системний підхід в аналізі експортно-імпортних операцій з агропродовольчими товарами як важливої ланки зовнішньої торгівлі з широким використанням методів та прийомів статистичного аналізу. Проаналізовано розвиток торгівлі агропродовольчими товарами з точки зору експортної виручки, величини та динаміки сальдо, динаміки та структури експортно-імпортних операцій. В дослідженні вказано на причини переважно сировинного характеру експорту, шо на думку авторів пов'язано з особливостями виробництва продукції в сільському господарстві та харчовій промисловості, а саме: високими темпами зростання продукції рослинництва і стагнацією в тваринництві, а також ситуацією в переробних підприємствах стосовно обсягів продукції, асортименту та якості, що поступається іноземним товарам. Аналіз досвіду ряду передових країн показує, що розвиток зовнішньої торгівлі має бути забезпеченим за рахунок нарощування не продукції рослинництва, а продукції тваринництва та готових харчових продуктів. У висновках представлено рекомендації стосовно зростання експорту продукції саме цих товарних груп, що вплине на товарну структуру та зменшить від'ємне сальдо по ряду товарних позицій.

Ключові слова: статистичний аналіз, прийоми статистичного аналізу, агропродовольча продукція, експорт, імпорт, сальдо, товарна структура, географрічна структура.

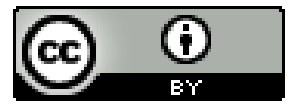

This work is licensed under a Creative Commons Attribution 4.0 International License http://creativecommons.org/licenses/by/4.0/
Постановка проблеми та її зв'язок $з$ важливими науковими та практичними завданнями. В зростанні експортного потенціалу держави, забезпеченні необхідних валютних надходжень важливе значення має експорт агропродовольчої продукції. В останні роки продукція сільського господарства та харчової промисловості стає головним експортним товаром. Проте слід зазначити, що основу агропродовольчого експорту становлять продукти рослинного походження, головним чином зернові та олійні культури, частка яких в загальному експорті поступово зростає. Натомість експорт готових харчових продуктів i, особливо, продуктів харчування зростає надзвичайно повільно, а їх частка в загальному експорті систематично зменшується. Необхідні зміни в експортній стратегії держави за рахунок нарощування експорту продукції з більшою доданою вартістю на основі організації промислових потужностей з комплексної переробки зернових, олійних та інших культур. Назріла необхідність змін в товарній структурі експорту агропродовольчої продукції та шляхів іiі реалізації і визначили актуальність дослідження.

Аналіз останніх публікацій 3 проблеми. Дослідження стану та тенденцій в зовнішній торгівлі агропродовольчими товарами висвітлені в роботах багатьох науковців: І.Г. Кириленко [5], Т.О. Осташко [6], М.І. Пугачова [9], С.А. Сегеда [10], Ю.О. Лупенка [11] та інших. Разом 3 тим, особливості функціонування ринку агропродовольчої продукції, динаміка експортно-імпортних операцій, товарна структура, зовнішні умови вимагають додаткових досліджень на основі раціонального використання експортного потенціалу.

Формування цілей дослідження. Метою да- 
ного дослідження $є$ оцінка за допомогою методів та прийомів статистичного аналізу сучасних рис зовнішньої торгівлі агропродовольчими товарами в розрізі товарної структури та обгрунтування заходів щодо раціоналізації існуючих структур шляхом збільшення експорту харчових продуктів з більшою доданою вартістю.

Виклад основних результатів та їх обгрунтування. Агропромисловий комплекс - один 3 найбільших в економіці України, в якому утворюється майже 15\% валового внутрішнього продукту держави. В останні роки АПК стає провідною галуззю вітчизняної економіки, що підтверджується обсягами та темпами зростання експорту агропродовольчих товарів. Продукція сільського господарства та харчової промисловості один з небагатьох видів товарів, експорт яких постійно зростає темпами, що значно перевищують збільшення загального товарного експорту.
В результаті цього частка агропродовольчої продукції в загальному експорті товарів в 2020 році зросла до 45,1 \%. Починаючи з 2014 р. агропродовольча продукція стає головним експортним товаром України, яким до цього були недорогоцінні метали та вироби 3 них, і це може свідчити про наявність серйозних проблем в економіці. Частка агропродовольчої продукції в товарному експорті України набагато перевищує аналогічні показники в розвинутих країнах та об'єднаннях. Так, в Свропейському Союзі - що є світовим лідером по експорту продовольства на ці товари в загальному обсязі європейського експорту приходиться лише 7 \% [12]. Проте, використовуючи сприятливу кон'юнктуру світового ринку і наявні можливості в певних секторах АПК в Україні швидко нарощується експорт сільськогосподарської продукції та продовольства (табл. 1).

Агропродовольча продукція в товарному експорті України*

\begin{tabular}{|c|c|c|c|c|c|c|c|c|c|}
\hline \multirow{2}{*}{ Показники } & \multicolumn{8}{|c|}{ Рік } & \multirow{2}{*}{$\begin{array}{l}2020 \mathrm{p} . \\
\text { у } \% \text { до } \\
2005 \mathrm{p} .\end{array}$} \\
\hline & 2005 & 2010 & 2015 & 2016 & 2017 & 2018 & 2019 & 2020 & \\
\hline $\begin{array}{l}\text { 1. Всього експорт товарів, } \\
\text { млрд. дол. }\end{array}$ & 34,3 & 50,7 & 38,1 & 36,4 & 43,3 & 47,3 & 50,1 & 49,2 & 143,4 \\
\hline $\begin{array}{l}\text { 2. Експорт агропродовольчої } \\
\text { продукцїі, млрд. дол. }\end{array}$ & 4,3 & 9,9 & 14,6 & 15,3 & 17,8 & 18,6 & 22,1 & 22,2 & 516,2 \\
\hline $\begin{array}{l}\text { 3. Частка агропродовольчої } \\
\text { продукції в загальному екс- } \\
\text { порті, \% }\end{array}$ & 12,5 & 19,5 & 38,3 & 42,0 & 41,1 & 39,3 & 44,1 & 45,1 & $\mathrm{x}$ \\
\hline $\begin{array}{l}\text { 4. Сальдо в торгівлі товара- } \\
\text { ми, млрд. дол. }\end{array}$ & $-1,8$ & $-9,6$ & 0,6 & $-2,8$ & $-6,3$ & $-9,9$ & $-10,7$ & $-5,1$ & $\mathrm{x}$ \\
\hline $\begin{array}{l}\text { 5. Сальдо в торгівлі агроп- } \\
\text { родовольчими товарами, } \\
\text { млрд. дол. }\end{array}$ & 1,6 & 4,2 & 11,1 & 11,4 & 13,5 & 13,6 & 16,4 & 15,7 & 9,8 рази \\
\hline
\end{tabular}

* Розраховано авторами за даними Державної служби статистики України [4]

За період 2005-2020 рр. експорт агропродовольчих товарів зріс на 17,9 млрд. дол., що дало можливість в певній мірі компенсувати скорочення експорту продукції хімічної промисловості, металургії та транспортних засобів (товарні групи VI, XV, XVII) загальною сумою 6976 млн. дол. і забезпечити зростання товарного експорту за цей період на 14,9 млрд. дол. Сальдо в торгівлі товарами зазвичай від'ємне, так як по більшості товарів 321 розділу відповідно УКТЗЕД, вартість імпорту перевищує обсяги експорту. Лише по агропродовольчій продукції, деревені та виробам $з$ дерева і недорогоцінним металам та виробам 3 них в результаті експортно-імпортних операцій отримується позитивне сальдо, близько 70 \% якого за даними 2019-2020 рр. приходиться на сільськогосподарську продукцію та продукцію харчової промисловості. Як свідчать дані табл. 1 в цей період нарощування агропродовольчого експорту супроводжується стрімким зростанням додатного сальдо, що позитивно впливає на стан торгового балансу держави.

Важливою характеристикою зовнішньої торгівлі являється товарна та географічна структура експортно-імпортних операцій. Товарна структура екс- порту агропродовольчих товарів відповідно до УКТЗЕД по розділах, товарних групах і товарних позиціях дає можливість встановити наскільки широку номенклатуру продукції країна може пропонувати на зовнішньому ринку. Основу агропродовольчого експорту в Україні традиційно становлять зернові та олійні культури, промислова продукція 3 незакінченим циклом виробництва (нерафіновані рослинні олії) та відходи і залишки харчової промисловості (товарні групи 1, 12, 15, 23). 3 часом, часка цих товарних груп лише зростає, так як абсолютно зростає експорт продуктів рослинного походженні і жирів та олії тваринного і рослинного походження, відповідно на 700,6 \% і 979,0 \%. Так, якщо в 2005 р. частка цих товарів в загальному агропродовольчому експорті становила $52,2 \%$, то в 2010 р. вона піднялась до 67,1 \%, в 2015 р. зросла до $81,2 \%$, а в 2020 р. досягла 83,8 $\%$.

Темпи зростання експорту тварин та продуктів тваринного походження і готових харчових продуктів є значно нижчими, ніж в середньому по агропродовольчій продукції, в результаті чого сумарна частка цих товарів в 2005-2020 pp. систематично 
скорочувалась $з$ 47,0 \% до 20,5\%.

Одним з важливих факторів, що визначають динаміку та структуру агропродовольчого експорту $\epsilon$ стан виробництва продукції сільського господарства та харчової промисловості.

Агропродовольча продукція в експорті та імпорті України - динаміка і структура*

\begin{tabular}{|c|c|c|c|c|c|c|c|c|c|}
\hline \multirow[b]{2}{*}{$\begin{array}{c}\text { Розділи продукції від- } \\
\text { повідно до УКТЗЕД }\end{array}$} & \multicolumn{2}{|c|}{$2005 \mathrm{p}}$. & \multicolumn{2}{|c|}{$2010 \mathrm{p}}$. & \multicolumn{2}{|c|}{$2015 \mathrm{p}}$. & \multicolumn{2}{|c|}{$2020 \mathrm{p}}$. & \multirow{2}{*}{$\begin{array}{l}2020 p . \\
\text { у \% до } \\
2005 \text { p. }\end{array}$} \\
\hline & $\begin{array}{l}\text { млн. } \\
\text { дол. }\end{array}$ & $\%$ & $\begin{array}{l}\text { млн. } \\
\text { дол. }\end{array}$ & $\%$ & $\begin{array}{l}\text { млн. } \\
\text { дол. }\end{array}$ & $\%$ & $\begin{array}{l}\text { млн. } \\
\text { дол. }\end{array}$ & $\%$ & \\
\hline \multicolumn{10}{|c|}{ Експорт } \\
\hline $\begin{array}{l}\text { 1. Живі тварини і про- } \\
\text { дукти тваринного по- } \\
\text { ходження }\end{array}$ & 732 & 17,0 & 771 & 7,8 & 823 & 5,7 & 1188 & 5,3 & 162,3 \\
\hline $\begin{array}{l}\text { 2. Продукти рослинно- } \\
\text { го походження }\end{array}$ & 1696 & 39,4 & 3950 & 40,1 & 7971 & 54,7 & 11883 & 53,6 & 700,6 \\
\hline $\begin{array}{l}\text { 3. Жири та олії тварин- } \\
\text { ного та рослинного } \\
\text { походження }\end{array}$ & 587 & 13,6 & 2605 & 26,5 & 3300 & 22,7 & 5747 & 25,9 & 979,0 \\
\hline $\begin{array}{l}\text { 4. Готові харчові про- } \\
\text { дукти }\end{array}$ & 1292 & 30,0 & 2524 & 25,6 & 2468 & 16,9 & 3361 & 15,2 & 260,1 \\
\hline Всього & 4307 & 100,0 & 9850 & 100,0 & 14562 & 100,0 & 22179 & 100,0 & 514,9 \\
\hline \multicolumn{10}{|c|}{ Імпорт } \\
\hline $\begin{array}{l}\text { 1. Живі тварини і про- } \\
\text { дукти тваринного по- } \\
\text { ходження }\end{array}$ & 500 & 18,6 & 1217 & 21,4 & 548 & 15,7 & 1258 & 19,4 & 251,6 \\
\hline $\begin{array}{l}\text { 2. Продукти рослинно- } \\
\text { го походження }\end{array}$ & 525 & 19,6 & 1527 & 26,9 & 1146 & 32,9 & 1989 & 30,6 & 378,8 \\
\hline $\begin{array}{l}\text { 3. Жири та олії тварин- } \\
\text { ного та рослинного } \\
\text { походження }\end{array}$ & 204 & 7,6 & 451 & 7,9 & 182 & 5,2 & 280 & 4,3 & 137,3 \\
\hline $\begin{array}{l}\text { 4. Готові харчові про- } \\
\text { дукти }\end{array}$ & 1455 & 54,2 & 2489 & 43,8 & 1608 & 46,2 & 2971 & 45,7 & 204,2 \\
\hline Всього & 2684 & 100,0 & 5684 & 100,0 & 3484 & 100,0 & 6498 & 100,0 & 242,1 \\
\hline
\end{tabular}

* Розраховано авторами за даними Державної служби статистики України [4]

Як видно $з$ даних табл. 2 експорт продукції рослинництва впродовж 2005-2020 рр. стабільно переважає обсяг експорту продукції тваринництва, при цьому ця тенденція посилюється. Якщо в 2005 р. частка продукції рослинництва складала 69,8 \% то в 2020 р. вона досягла рівня в 90,9\%, що пов'язується зі станом сільськогосподарського виробництва. За період 2005-2018 рр. продукція сільського господарства (в цінах 2010 р.) зросла 3179606 млн. грн. до 269408 млн. грн., або на 150,0 \%, при цьому продукція рослинництва збільшилась з 114480 млн. грн до 198658 млн. грн., або на 173,5 \%, в той час як продукція тваринництва за чотирнадцять років зросла лише на 108,6 \%. Частка продукції рослинництва за цей період збільшилась 3 63,7 \% до 73,7 \%. Виробництво зернових та зернобобових культур збільшилось 338015 тис. т. до 70056 тис. т. або на 184,3\%, а соняшнику 3 4706 тис. т. до 14165 тис. т. або на $301 \%$, що створило міцну базу для розвитку експорту зернових і соняшникової олії, по виробництву i експорту якої Україна є світовим лідером.

Тваринництво ж перебуває в стані постійної кризи: скорочується поголів'я сільськогосподарських тварин, а відтак, і виробництво продукції. За період 2005-2020 pр. виробництво молока скоротилося 3 13714 тис. т. до 9264 тис. т. або на 32,4 \%. Виробниц- тво яловичини та телятини в цей період скоротилось на 203 тис. т. Винятком тут є успішний розвиток птахівництва, експорт продукції якого і забезпечує зростання експертної виручки живих тварин та продукції тваринного походження.

Недостатній рівень виробництва продукції тваринництва, відсутність необхідних ресурсів, зменшує нашу присутність на зовнішніх ринках як експортерів. Як відомо, складовою ЗВТ між Україною та ЄС є встановлення безмитних тарифних квот на поставку певних видів товарів, в тому числі продуктів тваринництва: яловичина - 12000 т., м'ясо баранини 2250 т., свинина - 20000 т., м'ясо птиці - 20000 т., вершкове масло та молочні пасти - 3000 т. Реально освоюються квоти лише на двох останніх позиціях, а по м'ясу птиці квота перевищується в п'ять разів. По інших видах м'ясної продукції квоти використовуються на декілька відсотків по причині відсутності необхідних обсягів продукції. Більш того, по ряду позицій Україна виступає як чистий імпортер продукції тваринництва: м'ясо свинини, субпродукти, сири всіх видів, що в певній мірі вплинуло на перевищення в 2010 і в 2020 роках вартості імпорту над експортом по живих тваринах і продукції тваринного походження (табл. 2).

Найбільший імпорт в торгівлі агропродоволь- 
чими товарами здійснюється по готовим харчовим продуктам. Перевищення експорту над імпортом по цим товарам відбувається лише за рахунок товарної групи 23 «Залишки і відходи харчової промисловості». В аналізі експортно-імпортних операцій по готовим харчовим продуктам бажано виділити товарні групи 16-22, що включають продукти харчування i товарні групи 23 і 24 - «Тютюн і промислові замінники тютюну», що не являються такими [3]. Виручка від експорту продуктів харчування суттєво поступається імпорту формуючи значне від'ємне сальдо. Так, за період 2005 - 2020 років експорт продуктів харчування виріс з 1063 млн. дол. до 1344 млн. дол. або на
126,4 \%, а імпорт збільшився з 986 млн. дол. до 2133 млн. дол., тобто 216,3\%, а результат в торгівлі 377 млн. дол. додатного сальдо до від'ємного в сумі 789 млн. дол. Недостатні обсяги і темпи зростання продуктів харчування у порівнянні з імпортом пояснюються насамперед рядом проблем у вітчизняній харчовій промисловості: обсягами виробництва, асортиментом і якістю продукції, що поступаються іноземним товаpam.

Переважно сировинний характер вітчизняного агропромислового експорту особливо проявляється при порівнянні товарної структури ряду країн (табл. 3).

Таблиця 3

Порівняння товарної структури експорту агропромислової продукції в деяких країнах Свропи за 2019 рік*

\begin{tabular}{|c|c|c|c|c|c|c|c|c|c|c|}
\hline \multirow[b]{2}{*}{ Найменування товарів } & \multicolumn{2}{|c|}{ Україна } & \multicolumn{2}{|c|}{ PФ } & \multicolumn{2}{|c|}{ Польща } & \multicolumn{2}{|c|}{ Франція } & \multicolumn{2}{|c|}{ Білорусь } \\
\hline & $\begin{array}{l}\text { млн. } \\
\text { дол }\end{array}$ & $\%$ & $\begin{array}{l}\text { млн. } \\
\text { дол }\end{array}$ & $\%$ & $\begin{array}{l}\text { млн. } \\
\text { дол }\end{array}$ & $\%$ & $\begin{array}{l}\text { млн. } \\
\text { дол }\end{array}$ & $\%$ & $\begin{array}{l}\text { млн. } \\
\text { дол }\end{array}$ & $\%$ \\
\hline $\begin{array}{l}\text { 1.Живі тварини та продук- } \\
\text { ти тваринного похо- } \\
\text { дження }\end{array}$ & 1277 & 5,8 & 5142 & 20,4 & 10991 & 31,9 & 15285 & 21,2 & 3302 & 60,2 \\
\hline $\begin{array}{l}\text { 2. Продукти рослинного } \\
\text { походження }\end{array}$ & 12914 & 58,3 & 10448 & 41,5 & 5293 & 15,3 & 17133 & 23,8 & 662 & 12,1 \\
\hline $\begin{array}{l}\text { 3. Жири та олії тваринного } \\
\text { та рослинного похо- } \\
\text { дження }\end{array}$ & 4732 & 21,4 & 3441 & 13,6 & 515 & 1,5 & 1304 & 1,8 & 276 & 5,0 \\
\hline 4. Готові харчові продукти & 3220 & 14,5 & 6171 & 24,5 & 17719 & 51,3 & 38341 & 53,2 & 1244 & 22,7 \\
\hline Всього & 22143 & 100,0 & 25202 & 100,0 & 34518 & 100,0 & 72063 & 100,0 & 5484 & 100,0 \\
\hline
\end{tabular}

* Розраховано авторами за даними джерел [4], [7]

В Україні досить специфічна товарна структура експорту агропродовольчої продукції, що пояснюється особливостями сільського господарства та харчової промисловості. В порівнянні з іншими країнами в Україні найменший відсоток приходиться на живі тварини та продукти тваринного походження i готові харчові продукти, і найбільший відсоток - на продукти рослинного походження та жири і олії тваринного і рослинного походження. По абсолютному об'єму експорту Україна поступається Росій-

ській Федерації, Польщі і, особливо, Франції, і однією 3 причин такого положення може бут особлива товарна структура. Очевидно, що подальше нарощування експорту зернових, кукурудзи та олійних культур економічно недоцільно. Краще спрямувати кукурудзу на розвиток тваринництва, на виробництво спирту та етанолу. 3 приватизацією спиртових заводів, що нині успішно здійснюється, відкриваються можливості значного зростання виробництва і експорту спирту ректифікованого, спирту етилового технічного та біоетанолу, що користується попитом на світовому ринку. Географія експортних потоків спиртової продукції може включати країни Свропейського Союзу (Австрія, Польща, Угорщина, Словаччина), Азії (Грузія, Туреччина), СНД (Азербайджан, Туркменістан) та інші [8].

Вкрай недостатнім в Україні залишається експорт по товарній групі 11 «Продукція борошномельно-крупяної промисловості» у порівнянні з експор- том по товарній групі 10 «Зернові культури». Так, в 2019 році експорт продукції борошномельнокрупяної промисловості до експорту зернових культур склав (\%): Нідерланди - 127, Польща - 36,5, Франція - 14,7, Україна - 2,1. Це означає, що при збільшенні виробництва і експорту зернових культур слід паралельно нарощувати потужності промисловості на основі новітніх технологій по комплексній переробці зернових і отримання різноманітної продукції: корми для тваринництва, борошно, солод, крохмаль, готові харчові продукти із зерна, спиртопродукти і т.д. Це не тільки дозволить збільшити експорт, але і зменшити імпорт по товарах відповідних товарних груп. Особливості товарної структури агропродовольчого комплексу України впливають на географічну структуру і на формування переліку країн - найбільших імпортерів цієї продукції (табл. 4).

Для більшості країн з цього переліку основним імпортним товаром $є$ продукція товарних груп: 10 - «Зернові культури», 12 - «Насіння і плоди олійних культур», 15 - «Жири та олії рослинного і тваринного походження» та 23 - «Залишки і відходи харчової промисловості». Особливо такий характер імпорту стосується країн Азії [1]. У 2020 році на ці товарні групи прийшлось 98,0 \% імпорту в Китай, 93,6\% імпорту в Туреччину. В імпорті до Індії поступає з Україні нерафінована соняшникова олія - 96,7 \% всього імпорту продовольства.В країнах Європи перелік товарних груп більш різноманітний. 
ТОП -10 найбільших імпортерів агропродовольчої продукції з України

\begin{tabular}{|c|c|c|c|c|c|c|c|c|}
\hline \multicolumn{3}{|c|}{2018 рік } & \multicolumn{3}{c|}{2019 рік } & \multicolumn{3}{c|}{2020 рік } \\
\hline $\begin{array}{c}\text { № } \\
\text { 3/п }\end{array}$ & країна & \% у експорті & $\begin{array}{c}\text { № } \\
\text { 3/п }\end{array}$ & країна & \% у експорті & № 3/п & країна & \% у експорті \\
\hline 1. & Індія & 10,0 & 1. & Китай & 8,8 & 1. & Китай & 15,9 \\
\hline 2. & Китай & 6,3 & 2. & Сгипет & 7,8 & 2. & Індія & 6,7 \\
\hline 3. & Нідерланди & 6,2 & 3. & Індія & 7,0 & 3. & Нідерланди & 6,3 \\
\hline 4. & Іспанія & 5,6 & 4. & Туреччина & 7,0 & 4. & Єгипет & 6,2 \\
\hline 5. & Сгипет & 4,8 & 5. & Нідерланди & 6,6 & 5. & Туреччина & 4,8 \\
\hline 6. & Туреччина & 4,3 & 6. & Іспанія & 5,6 & 6. & Іспанія & 4,4 \\
\hline 7. & Італія & 3,8 & 7. & Німеччина & 3,9 & 7. & Польща & 3,4 \\
\hline 8. & Німеччина & 3,5 & 8. & Польща & 3,2 & 8. & Німеччина & 2,6 \\
\hline 9. & Саудівська & 3,2 & 9. & Італія & 3,1 & 9. & Італія & 2,5 \\
\hline 10. & Правія & Польща & 3,0 & 10. & Білорусь & 2,7 & 10. & Індонезія \\
\hline
\end{tabular}

*Розраховано авторами за даними Державної служби статистики України [4]

В значних обсягах імпортують з України продукцію товарної групи 02 - «М'ясо та їстівні субпродукти» - Нідерланди, Німеччина, 04 - «Молоко та молочні продукти, яйця птиці, натуральний мед» Німеччина, Польща. Проте тенденція переважання в імпорті сировинних товарів і напівфабрикатів характерна і для Свропейських країн [2].

Агропродовольчий експорт України, його обсяги та товарна структура повністю влаштовують імпортерів, які знаходять на нашому ринку необхідні їм товари. Сировинний характер агропродовольчого експорту це внутрішня справа держави і визначається рівнем вітчизняного виробництва, для зміни якого необхідні значні зусилля та великі кошти.

Висновки і перспективи подальших досліджень. Аналіз сучасного стану агропродовольчого експорту України засвідчує, що ця продукція користується великим попитом на світовому ринку. Темпи зростання експорту сільськогосподарської продукції та харчової промисловості значно перевищують темпи зростання товарного експорту України в цілому, в результаті чого частка цієї продукції у валютній виручці держави тільки зростає і значно перевищує аналогічний показник у розвинутих країнах. В товарній структурі експорту агропродовольчої продукції переважають сировина і напівфабрикати, що особливо помітно у порівнянні 3 рядом європейських країн. Такий стан зумовлений особливостями сільськогосподарського виробництва, та значною часткою в ньому, продукції рослинництва, а також недостатнім обсягом виробництва продукції харчової промисловості, що впливає на низький рівень експорту продукції тваринництва та продуктів харчування і зумовлює зростання імпорту.

Виконана оцінка стану зовнішньої торгівлі агропромисловими товарами свідчить, що ії подальший ефективний розвиток можливий лише за наступних умов:

- зміни в експортній політиці держави в плані удосконалення існуючої нині товарної структури при зростанні частки продукції тваринництва та готових харчових продуктів;

- формування значних експортних ресурсів шляхом нарощування промислових потужностей у комплексній переробці зернових, олійних та інших культур;

- створення відповідної інфраструктури, опрацювання маркетингу;

- організація системи моніторингу світового ринку агропродовольчих товарів по країнах світу, 3 метою виявлення нових споживачів вітчизняних товарів.

\section{Література}

1. Антонюк О.П., Антонюк П.О., Лисюк В.М. Країни Азії - головний партнер України в торгівлі агропродовольчими товарами // Економіка харчової промисловості. 2018. Т. 10, вип.2 С. 22-30. doi: 10.15673/fie.v10i2.957

2. Антонюк П.О., Антонюк О.П., Ступницька Т.М., Головаченко Л.М. Стан та результати торгівлі агропродовольчими товарами між Україною і Європейським союзом // Економіка харчової промисловості. 2019. T.11, вип.1. С. 27-36. doi: 10.15673/fie.v11i1.1292

3. Антонюк П.О., Антонюк О.П., Ступницька Т.М., Баранюк Х.О. Статистична оцінка формування зовнішньої торгівлі України готовими харчовими продуктами // Економіка харчової промисловості. 2021. Т.13, вип. 1. С. 3-11. doi: 10.15673/fie.v13i1.2006

4. Державна служба статистики України URL: http://ukrstat.gov.ua/ (дата звернення: 10.07.2021)

5. Кириленко І.Г., Івченко В.С., Деменчук В.В. Основні тенденції розвитку світового продовольчого ринку та виробництво продовольства в Україні // Економіка АПК. 2018. № 9. С. 34-35. doi: 10.32317/22211055.201809034 
6. Осташко Т.О. Експорт агропродовольчих товарів у СС: перспективи і завдання // Економіка і прогнозування. 2016. № 1. С.83-94. . doi: 10.15407/eip2016.01.083

7. Польша / Импорт и Скспорт / Весь Мир / Все товары 2008-2019. URL: https://trendeconomy.ru/data/h2/Poland?\%20time\%20period\%20=\%202019-2008 (дата звернення: 10.07.2021)

8. Приватизація спиртової галузі [Електронний ресурс]. URL: https:/privatization.gov.ua/alcoholindustry/ (дата звернення: 10.07.2021)

9. Пугачев М.І. Розвиток зовнішньої торгівлі агропродовольчими товарами // Економіка АПК. 2019. № 3. C. 6-13. doi: 10.32317/2221-1055.201903006

10. Сегеда С.А. Аграрно-продовольча продукція в товарній структурі зовнішньої торгівлі України // Економіка АПК. 2019. № 2. С. 73-83. doi: 10.32317/2221-1055.201902073

11. Формування глобального і регіонального ринків сільськогосподарської сировини та продовольства: монографія / Ю.О. Лупенко та ін. / за ред. Ю.О. Лупенка, М.І. Пугачова. Київ: ННЦ-ІАЕ-2015, 320 с.

12. ЕС стал мировым лидером по экспорту продовольствия: веб-сайт. URL: https://goo.su/7xnD (дата звернення: 10.07.2021)

Стаття надійшла 3.08.2021

Стаття прийнята до друку 17.08.2021

Доступно в мережі Internet 24.10.2021

Antonyuk P.

Ph.D., Researcher

Department of Market Mechanisms and Structures Institute of Market Problems and Economic \& Ecological

Research of National Academy of Sciences of Ukraine

Frantsuzskiy boulevard, 29, Odesa, Ukraine, 65044

E-mail: paul_antonyuk@ukr.net

ORCID ID: 0000-0002-8100-2563

Stupnytska T.

Ph.D., Associate Professor

Department of Accounting and Auditing

E-mail: t.stupnitska@gmail.com

ORCID ID: 0000-0002-2517-2795
Antonyuk 0.

Ph.D., Associate Professor

Department of Accounting and Auditing

E-mail: olegantoni@ukr.net

ORCID ID: 0000-0002-9182-4982

\author{
Baraniuk Kh. \\ Assistant \\ Department of Accounting and Auditing \\ Odesa National Academy of Food Technologies \\ Kanatna str., 112, Odesa, Ukraine, 65039 \\ E-mail: baranyuk.kristina@gmail.com \\ ORCID ID: 0000-0002-3346-0332
}

\section{ANALYSIS OF THE CURRENT STATE OF FOREIGN TRADE OF UKRAINE IN AGRI-FOOD PRODUCTS}

The article examines the current state of foreign trade in agri-food products based on the use of techniques and methods of statistical analysis. It was found that the export of these goods is developing most dynamically, as a result of which, starting from 2014, agricultural and food industry products become the main export product of Ukraine, and its share in the total export of goods reached $45.1 \%$ in 2020 , which is much higher than a similar indicator for developed countries and indicates the presence of serious problems in other sectors of the economy.

It was also noted that the export of these products provides the largest surplus in comparison with other goods, which affects the state of the country's trade balance.

During the analysis, it was revealed that the basis of agri-food exports is plant products, mainly cereals and oilseeds, the sales of which are growing both absolutely and relatively, which indicates the predominantly raw nature of this type of activity. The study of the reasons for this nature of the commodity structure of the export of agri-food products shows that they are hidden in the peculiarities of domestic production. In agriculture, crop production is mainly growing. Livestock production, on the other hand, grows very slowly. There are serious problems in the food industry - insufficient production volumes, a limited range of products, and product quality, which is inferior to foreign goods, which explains the growth of imports of food products.

A comparative analysis of the commodity structure of Ukraine and, less often, European countries shows that our competitors in the world market in their export policy are guided by the export of livestock products and finished food products, that is, products with high added value. In Poland and France, the sale of only these goods significantly exceeds the entire agri-food export of Ukraine. The paper emphasizes that the main way to improve the commodity structure is to increase responsible food production, which will increase the export of these products, reduce imports and increase the positive balance.

On the basis of the conducted study, recommendations have been presented to improve the efficiency of foreign trade in agri-food products in Ukraine.

Key words: statistical analysis, methods of statistical analysis, agri-food products, export, import, balance, commodity structure, geographic structure. 


\section{References}

1. Antonyuk O., Antonyuk P., \& Lysiuk, V. (2018). Krainy Azii - holovnyi partner Ukrainy v torhivli ahroprodovolchymy tovaramy. Food Industry Economics, 10(2), 22-30. doi: 10.15673/fie.v10i2.957

2. Antonyuk, P., Antonyuk, O., Stupnytska, T., \& Holovachenko, L. (2019). Condition and results of trading of the agri-food products between Ukraine and the European union. Food Industry Economics, 11(1), 27-36; doi: 10.15673/fie.v11i1.1292

3. Antonyuk, P., Antonyuk, O., Stupnytska, T. \& Baraniuk, Kh.(2021). Statistical assessment of formation of foreign trade of Ukraine in finished food products. Food Industry Economics,13(21), 3-11. doi: 10.15673/fie.v13i1.2006

4. Derzhavna sluzhba statystyky Ukrainy. Retrieved July 10, 2021, from http://ukrstat.gov.ua/

5. Kyrylenko, I. H., Ivchenko, V. Ye., \& Demenchuk, V. V. (2018). Osnovni tendentsii rozvytku svitovoho prodovolchoho rynku ta vyrobnytstvo prodovolstva v Ukraini. Ekonomika APK, (9), 34-35. doi: 10.32317/22211055.201809034

6. Ostashko, T. O. (2016). Eksport ahroprodovolchykh tovariv u YeS: perspektyvy i zavdannia. Ekonomika $i$ prohnozuvannia,(1), 83-94. doi: 10.15407/eip2016.01.083

7. Polsha / Import i Eksport / Ves Mir / Vse tovaryi 2008 - 2019. Retrieved July 10, 2021, from https://trendeconomy.ru/data/h2/Poland?\%20time\%20period\%20=\%202019-2008

8. Pryvatyzatsiia spyrtovoi haluzi. Retrieved July 10, 2021, from https://privatization.gov.ua/alcohol-industry/

9. Puhachev, M. I. (2019). Rozvytok zovnishnoi torhivli ahroprodovolchymy tovaramy. Ekonomika APK, (3), 6-13. doi: 10.32317/2221-1055.201903006

10. Seheda, S. A. (2019). Ahrarno-prodovolcha produktsiia v tovarnii strukturi zovnishnoi torhivli Ukrainy. Ekonomika APK, (2), 73-83. doi: 10.32317/2221-1055.201902073

11. Lupenko, Yu. O., \& Puhachov, M. I. (Eds.). Formuvannia hlobalnoho i rehionalnoho rynkiv silskohospodarskoi syrovyny ta prodovolstva. NNTs-IAE-2015.

12. ES stal mirovyim liderom po eksportu prodovolstviya. Retrieved July 10, 2021, from https://goo.su/7xnD

Received 3 August 2021

Approved 17 August 2021

Available in Internet 24.10.2021

Цитування згідно ДСТУ 8302:2015

Антонюк П.О., Антонюк О.П., Ступницька Т.М., Баранюк Х.О. Аналіз сучасного стану зовнішньої торгівлі України агропродовольчими товарами // Економіка харчової промисловості. 2021. Т.13, вип. 3. С. 16-22. doi: 10.15673/fie.v13i3.2128

Cite as APA style citation

Antonyuk, P., Antonyuk, O., Stupnytska, T. \& Baraniuk, Kh. (2021). Analysis of the current state of foreign trade of Ukraine in agri-food products. Food Industry Economics, 13(3), 16-22. doi: 10.15673/fie.v13i3.2128 